\title{
Soil and Water Conservation Measures in Ethiopia: Importance and Adoption Challenges
}

\author{
Negessa Gadisa ${ }^{1 *}$ and Tesfaye Midega $^{2}$ \\ Ethiopian Institute of Agricultural Research, Holeta Agricultural Research Center
}

\begin{abstract}
*Corresponding author: Negessa Gadisa, Ethiopian Institute of Agricultural Research, Holeta Agricultural Research Center.
\end{abstract}

Received Date: January 11, 2021

Published Date: January 29, 2021

\begin{abstract}
Soil and water are under immense pressure due to ever increasing population thereby ensuing growing demand for food, fiber and shelter. Soil erosion is one of the several major deteriorative processes which results in soil degradation and declining agricultural productivity in Ethiopia. Thus, several efforts to control soil erosion through introduced soil and water conservation measures had been conducted in different time and location in the country. A number of soil and water conservation methods were introduced to combat land degradation, but adoption of these practices did not achieve the target. Different soil and water conservation measures and farmer's adoption barriers on these conservation measures had been reviewed here. Literature indicated that soil and water conservation measures have promising effects on reducing soil loss, retaining nutrient and soil moisture, improving soil physical and chemical properties. But an intensive labour requirement, poor design, reduced land size and other biophysical and socioeconomic factors discourage farmer's adoption of soil and water conservation structures. The involvement of Farmers and strengthen extension workers as well as mainstreaming soil and water conservation activity in any agricultural development project has a vital role in these resource conservations.
\end{abstract}

Keywords: Agricultural production; Farmers adoption; Moisture and nutrient retention

\section{Introduction}

Soil degradation is the loss of soil productivity quantitatively or qualitatively through various processes like erosion, acidification, salinization, nutrient depletion, and deterioration of soil physical properties; of which soil erosion is the most contributing process to unsustainable agricultural productivity in most developing countries. Soil erosion is the most dangerous ecological process observed in Ethiopia, degrading the precious soil resources which are the basis of agricultural production and food for the country's people and which provide numerous other ecosystem services.

The speed and extent of soil degradation depends on different factors especially soil type, relief, climate, and farming system. Due to difference in these factors, the distribution of soil erosion in the country is different. The Hararghe highlands in Eastern Ethiopia, Tigrai, Wollo, and Semen Shewa highlands in the North and the
Gamo-Gofa highlands and the Bila-te River basin, which starts in Eastern slopes of Gurage highlands and stretches through Eastern Hadiya and Kembatta highlands, are some of the seriously eroded land surfaces in Ethiopia [1].

The Ethiopian government first recognized the severity of soil degradation problem following the 1973-1974 famine [1]. As soil productivity loss due to erosion goes on increase, the issues of soil erosion \& conservation became questions of survival. Many endeavors were carried out by the Ethiopian government to combat the land degradation problem. The Ethiopian government launched a massive soil conservation Programme which includes physical and biological conservation measures in between 1976 and 1992 ([2] W/Aragaye Berehe 1996; EFAP 1994 as cited by Tamire [1]). According to this paper, 78,000 ha, 253,000 ha, 580,000 ha, 15,400 
$\mathrm{km}$ of land is covered with soil and stone bunds, hill side terraces and afforestation, bench terraces and check dams in gullied lands respectively whereas 410,000 ha were area enclosure and 465,000 ha planted with different tree species. However, yet the achievements were far below the expectation and the country has been losing incredible amount of precious top fertile soil annually.

Hurni [3] estimated that soil loss due to erosion in Ethiopia amounts to 1493 million tons per year, of which about 42 tons/ha/ yr is estimated to have come from cultivated, whereas only 5 tons/ ha from pastures. As a result, nearly half the soil loss comes from land under cultivation, even though these lands cover only $13 \%$ of the country. This is far greater than the maximum tolerable soil loss (18 t/ha/yr) as well as the annual rate of soil formation in the country. A study in the Central Rift Valley of Ethiopia by Derege et al. [4] indicated that there was a marked increase in soil erosion rates from 1973 to 2006, with annual rates of 31 t/ha in 1973 and $56 \mathrm{t} /$ ha in 2006. They attributed the increasing soil erosion rates to the conversion of forests or woodlands to croplands since soil loss rates from crop land is obviously greater than that of forest land. Some recent research findings also support this truth. For instance, Adugna [5] estimated the soil losses at Northeast Wollega by using the Revised Universal Soil Loss Equation (RUSLE) and obtained a variation that range from $4.5 \mathrm{t} / \mathrm{ha} / \mathrm{yr}$ in forest to 65.9 t/ha/ yr in cropland. In addition, some researchers observed the spatial variation of soil degradation. Nigussie et al.,2015, reviewed and compiled soil loss rates caused by sheet and rill erosion at plot and catchment scales and indicated that this soil degradation process varies strongly spatially, with a mean soil loss $29.9 \mathrm{t} / \mathrm{ha} /$ yr $(S D=30.2 \mathrm{t} / \mathrm{ha} / \mathrm{yr}, \mathrm{n}=25)$. The highest rates were observed in Anjeni (110 t/ha/yr) and Chemoga (102t/ha/yr) of the Upper Blue Nile Basin. Thus, this author concluded that soil loss estimation at national level is still tentative and inconsistent.

Even though the data on soil loss estimation in Ethiopia are inconsistent, they can urge that the present status and rate of soil erosion in Ethiopia call for immediate action to retard and reverse this soil degradation due to erosion process. One method of reversing this soil degradation is to use different soil and water conservation measures. But some soil and water conservation measures have faced challenges from farmers in Ethiopia. Therefore, this review paper generally focuses on the importance of soil and water conservation measures and their adoption challenges in Ethiopia.

\section{Types of Soil and Water Conservation Measures in Ethiopia}

Many soil and water conservation measures (SWC) have been carried out at individual or community levels in Ethiopia. The study in Meket Woreda of North Eastern Ethiopia identified the most common soil and water conservation practices in the area such as physical structures like soil bunds, stone bunds, soil-stone bunds, check dam, hill side terraces while the agronomic practices includes area enclosure, traditional ditches, contour plowing, grass strips [6]. A field survey conducted in Goromti watershed found that Soil bund, fanya juu, water way, cut off drain and grass strips are the major soil and water conservation measures adopted in the area [7]. Similarly, Mushir [8] conducted a field survey and found that farmers in Siliti woreda uses practices such as fallowing land, contour ploughing, manuring, crop rotation, afforestation, drainage ditches, cut off drains, check dams, leaving crop residues, Fanya juu and terraces for the soil and water conservation. Mubarek [9] identified the main SWC measures found in Wegdi woreda such as soil and stone bunds, tree planting, agro-forestry, strip cropping, inter cropping, cut-off drains, water ways, modern check dams and contour ploughing.

Some researcher studied soil and water conservation measures by classifying them into indigenous and introduced measures whereas others classified as agronomic, physical and biological measures. Birhan [6] identified indigenous SWC measures (traditional dithes (boyi), traditional waterway (Gorf Mekided), mixed cropping, contour ploughing, crop rotation and dib) and newly introduced SWC practices (soil bunds, stone bunds, stonefaced soil bunds, hillside terrace, check dams, sediment storage dams, micro basin and cut off drain) at Gidan Wereda of North Wollo. A study in Bale Eco-Region by Tadele [10] identified different soil conservation practices: indigenous agronomic (fallowing, crop rotation and intercropping), physical practices (traditional terrace, modern terrace, soil bund and counter ploughing) and biological practices (Agroforestry, grass strips, cutting and carrying, traditional rotational grazing and haymaking). In the same way, Belay and Eyasu [11] assessed and classified the major SWC measures being employed in Guba-Lafto Woreda of North Wollo as physical SWC measures (stone bund, hillside terrace, micro water ponds, stone faced soil bund, check dam, and fanya-juu terrace); agronomic conservation measures (contour farming, agroforestry, mixed cropping, and crop rotation); and biological conservation measures (afforestation, area enclosure, and grass strip).

The result of study conducted to assess farmers' practices on soil erosion control and soil fertility improvement in rift valley areas of east Shewa and west Arsi zones of Oromia region showed that farmers are using different practices such as soil bund, cutoff drains and micro basins, crop rotation, compost, animal manure and intercropping to control soil erosion problem [12]. According to Mengie et al. [13], some of the adopted soil conservation practices in Darimu and Chewaka woredas of Illu Ababora Zone include fallowing, manure, contour plowing, crop rotation, waterways, terracing, soil bund, funya juu, grass strip, chomo grass and elephant grasses. Samuel [14] identified some of the common indigenous SWC practices in the east Haraghe zone such as Mechanical SWC practices (soil bund, stone bund, terrace, micro-basin and tied 
ridge), biological SWC practices (grass for structure stabilization and tree plantation) and Agroforestry practices (algae check dam, sifting cultivation).
Zenebe et al. [15] reviewed and summarized the most common SWC measures in Ethiopia by grouping them into three broad categories: farmland management, hillside management and gully rehabilitation/stabilization (Table 1).

Table1: Selected SWC practices in Ethiopia categorized based on management types.

\begin{tabular}{|c|c|c|}
\hline Farmland Management & Hillside Terrace & Gully Rehabilitation / Stabilization \\
\hline Soil bund & Hillside terrace & stone check dam \\
\hline Stone bund & Diversion ditch & Gabion check dam \\
\hline Stone faced soil bund & Stone faced trench & Sediment storage dam \\
\hline Double stone-faced soil bund & Micro -basin & Live check dam \\
\hline Fanya juu terrace & Bench terrace & stone check dam \\
\hline Tied ridges & Semi-circular terrace & Gully reshaping and planting \\
\hline Bench terrace & Eyebrow basin & sand/soil filled check dam \\
\hline Zai pit & Deep trench & Cut-off drains \\
\hline Trash line & Terrance and trench & Diversion dicch \\
\hline Cut-off drains & Cut-off-drains & Waterways \\
\hline Waterways & .
\end{tabular}

Source: Zenebe et al. (2018)

\section{Soil and Water Conservation Measures in Ethiopia}

The roles of soil and water conservation measures in reducing nutrient and soil losses, and hence increasing agricultural productivity have been reported by several researchers. Yonas et al. [16] evaluated the effectiveness of soil and water conservation practices on improving selected soil properties in Wonago district, Southern Ethiopia. They found that soil pH, K, P, TN, SOC, \%clay and CEC were significantly improved in areas with SWC practices. The use of SCW measures could change P and C factors used in RUSLE equation. For instance, Tibebu et al. [17] assessed soil erosion control efficiency of land management practices implemented (for 5 years: 2010-2015) through free community labor mobilization in 16 systematically selected watersheds of Ethiopia. The result showed that overall change in $\mathrm{P}$ and $\mathrm{C}$ factor values resulted in a $42 \%$ relative soil loss reduction in the selected watersheds.

\section{Bench and hillside terraces}

A bench terrace is a conservation structure where a slope is converted into a series of steps, with a horizontal cultivated area on the step and steep risers between two steps (Figures 1 and 2). In Ethiopia, a bench terrace is usually developed from bunds and Fanya Juus over a period of 5-15 years through careful maintenance and buildup [18]. Bench terraces are level along the contour in dry to moist agroecological zones. In moist to wet agroecological zones, they are graded to drain excess runoff sideways to the next river or waterway. Levelling the cultivated land will greatly reduce soil erosion, usually to tolerable amounts.

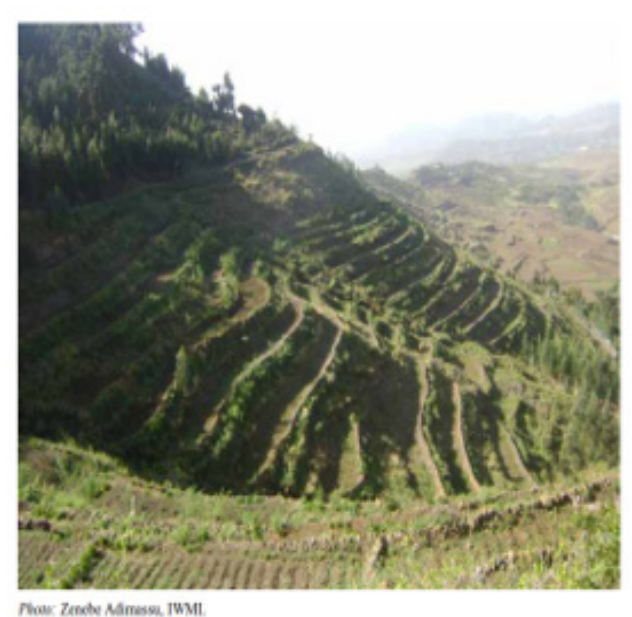

Figure 1: Bench terrace in Tigray. 


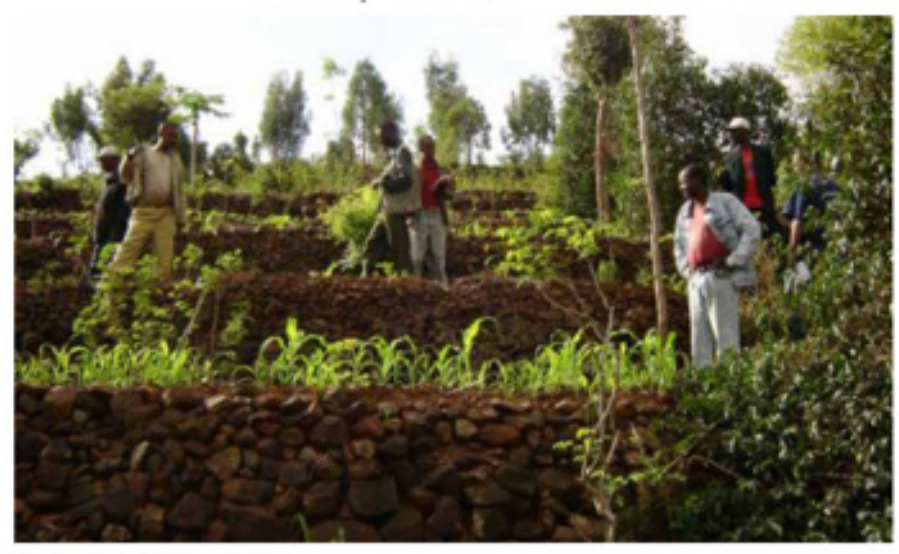

Photo: Zenebe Adimassu, IWML.

Figure 2: Bench terrace in Konso.
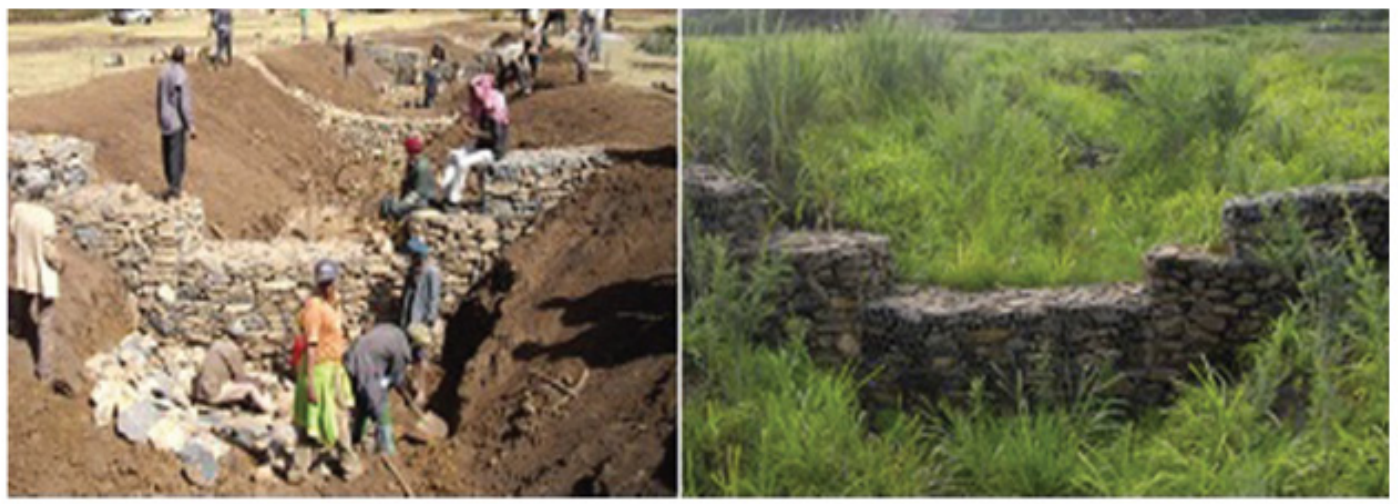

Figure 3: Check dam.

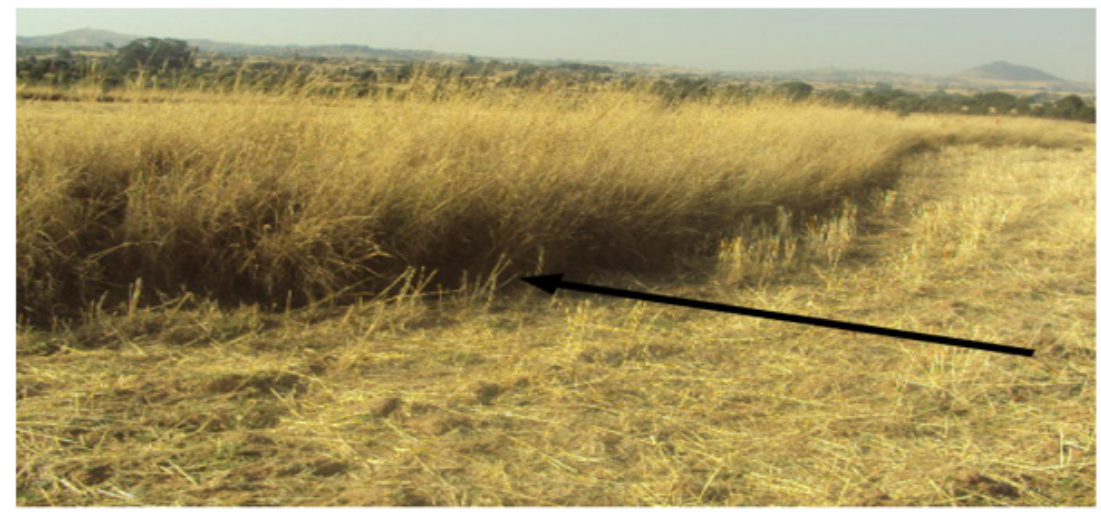

Figure 4: Grass strip.

A hillside terraces are a structure along the contour, where trips of lands are levelled for tree planting. They help to retain runoff and sediment on steep sloping land and to accommodate tree seedlings planted on them.

\section{Level and graded soil bunds}

A level bund is an embankment along the contour, made of soil and/or stones, with a basin at its upper side. The bund reduces or stops the velocity of overland flow and consequently soil erosion. Soil which is eroded between two bunds is deposited in the basin behind the lower bund. Soil bunds reduced soil losses and runoff by $35 \%$ and $15 \%$ respectively [19].

Graded bunds are slightly graded sideways, with a gradient of up to $1 \%$, towards a waterway or river. They can retain normal amounts of runoff in their basins, but they can drain excess runoff 
from heavy storms which would cause overflow and downslope destruction on level bunds. Most of the soil eroded between two bunds is deposited, while some will be drained sideways during heavy storms and lost from the land. However, graded bunds are more effective than level bunds in wet and moist areas with clay soils. Some studies showed that graded soil bund reduced runoff, soil and nutrient losses. Zenebe et al. [20] studied the effects of graded soil bunds on runoff and losses of soil and nutrients for 3 years (2007-2009). The results showed that Soil bund brought about significant reduction in average annual runoff $(28 \%)$ and soil losses (47\%). Consequently, Soil bund reduced losses of soil organic carbon (51.4\%) and soil nutrients like N, P, and K by $48 \%$, $54 \%$ \&, and $47 \%$, respectively.

\section{Level and graded fanya juu}

A level fanya iuu ('throw uphill' in Swahili language) is an embankment along the contour, made of soil and/or stones, with a basin at its lower side. The fanya juu reduces or stops the velocity of overland flow and consequently soil erosion. Soil eroded between two fanya juus is deposited behind the lower one. This deposition of soil behind the fanya juu can increase crop yield. Yohannes [2] compared barley crop and biomass yields above (soil accumulation area) and below (soil loss area) of fanya juu terraces in the Andit Tid area of northern Shewa in three cropping seasons and obtained average barley yield of $1650 \mathrm{~kg}$ per ha above the fanya juu, which was $43 \%$ higher than below the fanya juu.

A graded fanya juu is slightly graded sideways towards a waterway, with a gradient of up to $1 \%$. This gradient is for surplus runoff to be drained if the retention of the fanya juu is not sufficient. Graded fanya juu retains small amounts of runoff above their wall and they drain excess runoff from heavy storms through the ditch below. Some of the soil eroded between two fanya juus is deposited above the wall, some is deposited in the ditch, and the rest is drained sideways.

\section{Check dam}

A check dam is an obstruction wall across the bottom of a gully or a small river to reduce the velocity of the runoff and prevent deepening or widening of the gully and help to fill it up with sediment (Figure 3). The potential energy is absorbed below the vertical drops of the over-fall. Sediments are deposited behind the check dams so that the slope gradient of the gully is also reduced.

\section{Cut-off drain, water ways and contour farming}

A cutoff drain is a channel used to collect runoff from the land above and to divert it safely to a waterway or river, thus protecting the land below from excessive erosion. The farmers construct these drains to prevent loss of seeds, fertilizers, manure and soil due to water flowing onto the plot from uphill.

A waterway is a natural or artificial channel along the steepest slope or in the valley used to accommodate runoff to be drained safely to the next river. They need to be paved with grasses or stone. Contour farming is a method of creating furrows perpendicular to the predominant field slope. It is being adopted in modern agriculture across the world for soil erosion control. The furrows retard the runoff velocity, reduce the runoff transport capacity, enhance water infiltrability, and reduce sediment transport and discharge excess runoff at non-eroding velocities.

\section{Conservation tillage and mulching}

Conservation tillage is a tillage practice aimed at creating a favorable soil environment for germination, establishment and plant growth with minimal soil disturbance. It reduces or avoids full ploughing operations, which are used to remove weeds and prepare moisture uptake but destroy the soil structure and disturb soil organisms. Conservation tillage reduces runoff and conserves water in the soil after the soil organisms soften the soil. It greatly reduces erosion, improves the soil structure and conserves organic matter in the soil.

Applying mulch means covering the soil with crop residues such as straw, maize and sorghum stalks, tree leaves, or other plant material, or standing stubble. The cover protects the soil from the hot sun and from the impact of raindrops, minimizing soil crusting, runoff and erosion, and also used for the restoration and maintenance of soil fertility.

\section{Alley cropping and grass strip}

Alley cropping is an agroforestry system in which food crops are grown in alleys between rows of hedges. The hedges follow the contour and consist of trees and shrubs especially leguminous perennials since they can fix nitrogen. Hedges can also be placed on conservation structures. Trees and shrubs provide green manure or mulch for recycling nutrients to the soil. Bunds on steeper slopes are stabilized and hence reduce soil erosion.

A grass strip is a ribbon-like band of grass laid out on cultivated land along the contour. Grass Strips help to reduce runoff and to filter out sediments carried by runoff (Figure 4). They are especially suitable on soil with good infiltration on gentle slopes and where the climate is not too dry for dense grass development.

\section{Area enclosure and controlled grazing}

Area closure is a protection system to improve land with degraded vegetation and/or soil through natural regeneration. No livestock are allowed to graze, and no human interference tolerated for 2-3 years, until a 50\% natural grass cover is obtained [18]. Soil conservation is best attained through dense ground cover by grass and legumes, while roots stabilize the soil.

Controlled grazing is defined as direct utilization of grassland with livestock in such a way that no degradation of vegetation and 
soils occurs, allowing the grass to recover and to retain the quality of the rangeland.

\section{Adoption Challenges of Soil and Water Conservation Measures in Ethiopia}

There are barriers or challenges for farmers to adopt Soil erosion control measures in Ethiopia. As Nigussie [21] reviewed, some of these challenges include, labor unavailability, limited capital, lack of or limited incentives and benefits (e.g., food for work), insecure land tenure policy, inappropriate technology choices (not fit to local conditions), lack of technologies that provide quick returns for subsistent farmers, weak technical support from development agents and officers, and poor community participation (due to command-and-control policies). Belay and Eyasu [11] assessed the main challenges and extents of implementation of soil and water conservation (SWC) measures in Guba-Lafto Woreda of North Wollo. This study indicated that lack of awareness on SWC, land shortage, labor shortage, and wealth status of the farmers were challenging the households to implement SWC practices on their farmlands.

Field survey conducted in Goromti watershed revealed that factors such as slope of the area, contact with extension workers, tenure status, age, size of household and training influenced farmers to adopt soil and water conservation measures [7]. Even some farmers failed to maintain adopted soil conservation measures mainly due to the reduced plot size by conservation measures, poor design, and lack of labor and incentives. A study conducted by Zenebe et al. [20] indicated that soil bund reduced the cultivable area by $8.6 \%$ and hence crop yield was reduced by about $7 \%$ as compared with control plots. The result of another field survey conducted to examine factors affecting adoption of introduced soil and water conservation practices in Wereillu Woreda indicated that the age of household heads, off-farm activity, and distance of farmlands from homesteads influenced the adoption of introduced soil and water conservation practices negatively [22].

Similarly, a study undertaken in Meket Woreda of North Eastern Ethiopia identified, participation in off farm activities has a negative and significant influence on the adoption of soil and water conservation measures [6]. Nigatu [23] reviewed farmers perception on soil and water conservation practices in Ethiopia and found major constraints that determine the implementation of soil and water conservation in Ethiopia such as lack of integrated bio-physical measures, absence of integrating indigenous practices, lack of considering socio-economic profile, low perception and participation of farmers, poor conservation design, improper land use, less maintenance, weak monitoring and evaluation of soil and water conservation practices. The result of a study by Mengie et al., [13] also revealed that the major challenges of adopting structural soil conservation mechanisms in Darimu and Chewaka woredas of Illu Ababora Zone includes: geographical aspect, insecure land tenure, low educational level, weak extension services, sex of the household, lack of awareness about soil conservation methods and participation on off farm activities.

Mubarek [9] assessed factors influencing the adoption of structural soil and water conservation (SWC) technologies for sustainable watershed management and planning in Wegdi district. He found that household size, farmland size, labor, perception of soil erosion problem, and training service in soil erosion control, land tenure; access to institutional services, and farmland distance from homesteads had an impact on adoption of introduced structural SWC technologies. The major problems related to conservation structures for farmers in Siliti woreda include pests, inconveniency during oxen ploughing, reduction of farmland, labor intensiveness, difficulty in implementation, and costliness [8]. Similarly, Adugnaw [24] investigated factors influencing continued use of structural SWC Practices in Farta District. The result showed that only $47.2 \%$ of the respondents continually used the structural conservation measures and the remaining were not due to different factors, of which perception of farmers on erosion and technology profitability was the major factor followed by institutional factors including tenure security, extension contact, access to training and membership in local organizations.

\section{Conclusion and Recommendations}

Soil erosion is the most dangerous ecological process observed in Ethiopia, degrading the precious soil resources which are the basis of agricultural production and food for the country's people and which provide numerous other ecosystem services. As soil productivity decreased as a result of erosion increased, the issues of soil and water conservation became a question of human survival. Many endeavors were carried out by the Ethiopian government to combat the land degradation problem. However, yet the achievements were far below the expectation and the country has been losing incredible amount of precious top fertile soil annually which in turn trap the country in vicious cycle of poverty and food insecurity. Thus, the present status and rate of soil erosion in Ethiopia call for immediate action to retard and reverse this soil degradation due to erosion process. One method of restoring soil degradation was to use different soil and water conservation measures. But soil and water conservation measures have faced challenges from farmers in Ethiopia due biophysical and socio-economic factors to gather with weak extension service and lack education in the community. Therefore, this review paper focuses on the types and importance of soil and water conservation measures, and their adoption challenges in Ethiopia. Soil and water conservation which mainly focus on physical structures had been conducted in different times and agro-ecologies. These includes different forms of bunds, fanya juu, bench terraces and ditches 
are the commons. However, there are challenges for farmers to adopt Soil erosion control measures in Ethiopia. Some of these common challenges include labor unavailability, insecure land tenure, land shortage, lack of integrated bio-physical measures, lack of considering socio-economic profile, weak monitoring and evaluation of soil and water conservation practices, weak extension services, inconveniency during oxen ploughing, and reduction of farmland. In order to improve adoption rate of SWC measures by the Ethiopian farmers, soil and water conservations should consider the following issues:

- Institutions working on Agriculture have to become aware that no development activity is effective unless integrated with conservation activity and ecological restoration.

- $\quad$ Farmers should be participated during planning and implementation of SWC measures so that social, political, cultural and economic statuses of the farmers get consideration.

- Extension capacity should be improved especially with respect to sustainable land management plan.

- Farmers land certification should be implemented in all areas of Ethiopia to make farmers feel secure in their land.

\section{Acknowledgement}

None.

\section{Conflict of Interest}

No conflict of interest.

\section{References}

1. Tamirie Hawando (1997) Desertification in Ethiopian Highlands. RALA REPORT NO. 200, Norwegian Church AID, Addis Ababa, Ethiopia.

2. Yohannes GM (1989) Crop Production and Conservation Methods in Andit Tid Area, Northern Shewa. Soil Conservation Research Project, Addis Ababa.

3. Hurni H (1993) Land Degradation, Famine and Resource Scenarios in Ethiopia. In: Pimentel, D., Ed., World Soil Erosion and Conservation, Cambridge University Press, Cambridge, pp. 27-62.

4. Derege Tsegaye, Atsushi Tsunekawa, Mitsuru Tsubo, Nigussie Haregeweyn (2012) Analysis of the Dynamics and Hotspots of Soil Erosion and Its Management Scenarios: The case of the Central Rift Valley of Ethiopia. International Journal of Sediment Research 27: 84-99.

5. Adugna A, Abegaz A, A Cerda (2015) Soil Erosion Assessment and Control in Northeast Wollega, Ethiopia. Journal of Solid Earth Discuss 7: 3511-3540.

6. Birhan Sisay (2009) Factors Affecting the Adoption of Soil and Water Conservation Practices in North Eastern Ethiopia. A Case of Meket Wored. MA Thesis. Addis Ababa University, Addis Ababa, Ethiopia.

7. Addisu Damtew (2011) Benefits and Challenges of Adopting Soil Conservation Techniques in Goromti Watershed, Cental Ethiopia. MSc Thesis. Addis Ababa University, Addis Ababa, Ethiopia.

8. Mushir Ali, Kedru Surur (2012) Soil and Water Conservation Management through Indigenous and Traditional Practices in Ethiopia: A Case Study. Ethiopian Journal of Environmental Studies and Management 5(4): 343355.
9. Mubarek Ahmed (2014) Farmers' practice and factors influencing the adoption of soil and water conservation measures in Wegdi Woreda, South Wollo, Ethiopia. MSc Thesis. Addis Ababa University, Addis Ababa, Ethiopia.

10. Tadele Kifle (2016) Land Management Practices and their Contribution to Livelihoods and Land Resources Conservation in Bale Eco-Region, South Eastern Ethiopia. MSc Thesis. Hawassa University, Wondo genet, Ethiopia.

11. Belay Asnake, Eyasu Elias (2017) Challenges and Extents of Soil and Water Conservation Measures in Guba-Lafto Woreda of North Wollo, Ethiopia. E3 Journal of Agricultural Research and Development 7(2): 103-110.

12. Tesfaye Gemechu, Kasahun Kitila (2017) Assessment of Farmers' Practices on Soil Erosion Control and Soil Fertility Improvement in Rift Valley Areas of East Shoa and West Arsi zones of Oromia, Ethiopia. African Journal of Water Conservation and Sustainability 5(5): 227-234.

13. Mengie Belayneh, Alemayehu Abera, Gashahun Tadesse (2017) Soil Degradation and Conservation Practices: The case of Darimu and Chewaka woredas, Illu Ababora Zone, Ethiopia. International Journal of Scientific and Research Publications 7(10): 562-568.

14. Samuel Lindi (2018) Assessment of Indigenous Soil and Water Conservation Practices of East Hararghe Zone, Ethiopia. Academia Journal of Environmental Science 6(2): 20-36.

15.Zenebe Adimassu, Langan S, J Barron (2018) Highlights of Soil and Water Conservation Investments in Four Regions of Ethiopia. Colombo, Sri Lanka: International Water Management Institute (IWMI). 35p. IWMI Working Paper 182.

16. Yonas Ademe, Temesgen Kebede, Alemayehu Mullatu, Toyiba Shafi (2017) Evaluation of the Effectiveness of Soil and Water Conservation Practices on Improving Selected Soil Properties in Wonago District, Southern Ethiopia. Journal of Soil Science and Environmental Management 8(3): 70-79.

17. Tibebu Kassawmar, Gizaw Desta, Gete Zeleke, Alemtsehay Subhatu (2018) International Soil and water Conservation research 6: 87-98.

18. Hurni H, Berhe WA, Chadhokar P, Daniel D, Gete Z, et al. (2016) Soil and Water Conservation in Ethiopia: Guidelines for Development Agents. Second revised edition. Bern, Switzerland: Centre for Development and Environment (CDE), University of Bern, with Bern Open Publishing (BOP). $134 \mathrm{pp}$.

19. Amare T, Zegeve AD, Yitaferu B, Steenhuis TS, Hurni H, et al. (2014) Combined Effect of Soil Bund with Biological Soil and Water Conservation Measures in the Northwestern Ethiopian Highlands. Ecohydrology and Hydrobiology 14(3): 192-199.

20. Zenebe A, Mekonnen K, Yirga C, A Kessler (2014) Effect of Soil Bunds on Runoff, Soil and Nutrient Losses, and Crop Yield in the Central Highlands of Ethiopia. Land Degradation Development 25(6): 554-564.

21. Nigussie Haregeweyn, Atsushi Tsunekawa, Jan Nyssen, Jean Poesen, Mitsuru Tsubo, et al. (2015) Soil Erosion and Conservation in Ethiopia: A Review. Progress in Physical Geography, pp. 1-25.

22. Daniel Asfaw, Mulugeta Neka (2017) Factors Affecting Adoption of Soil and Water Conservation Practices: The Case of Were Illu Woreda, South Wollo Zone, Amhara Region, Ethiopia. International Soil and Water Conservation Research 5(4): 273-279.

23. Nigatu Dabi, Kalkidan Fikirie, Tewodros Mulualem (2017) Soil and Water Conservation Practices on Crop Productivity and Its Economic Implications in Ethiopia: A Review. Asian J Agric Res 11(4): 128-136.

24. Adugnaw Birhanu, Desalew Meseret (2013) Structural Soil and Water Conservation Practices in Farta District, North Western Ethiopia: An Investigation on Factors Influencing Continued Use. Science, Technology and Arts Research Journal 2(4): 114-121. 